\title{
ADMINISTRATIVE JUSTICE AND THE ROLE OF DISCRETION
}

\section{BY ROBERT M. COOPER †}

THE EXERCISE of discretionary authority by administrative agencies has probably been subjected to more criticism than any other task of governmental administration. ${ }^{1}$ And yet from the viewpoint of the administrator and the student of public administration, the place of discretion within the pattern of government is no less important nor dispensable than the more fundamental aspects of political democracy. ${ }^{2}$ Among those opposed to the use of discretion by administrative officials, the argument has seldom passed beyond the stage of unpleasant epithets. ${ }^{8}$ All too frequently the exercise of discretion is loosely characterized by reference to some such vague symbolism as "tyranny," "despotism," or "bureaucracy." At its best, such conceptual criticism hardly reaches above the level of emotional reaction. This blind hostility and suspicion toward a legitimate administrative function is largely the result of a misunderstanding as to the basic problems of government which manifests itself in several different ways. In many instances this critical attitude reveals what appears to be a total misconception of the character

fSpecial Assistant to the Attorney General of the United States.

1. New York Judiciary Constitutional Convention of 1921, REPORT ro LEGisLnturs, Legislative Document No. 37, (1922) 10; Beck, Our Wondencand of Buneaucracr (1932); Sutherland, Private Rights and Govermment Conirol, (1917) 85 CErr. L. J. 168; Burgess, Recent Efforts to Immurize Commission Orders Against Judicial Recriew, 55 A. B. A. Report 731 (1930); Report of the Spectal Corousttrez on Adurnistzatitz LAw of the AsIerican Bar Assoctation, 61 A. B. A. Refort, 720 (1936).

2. See Dimock, The Role of Discretion, in Frontmens of Pumatc Adumnsmamon (1936) 45; Laski, The Growth of Admirsistrative Discretion, (1923) $1 \mathrm{~J}$. Pun. AD2rn. 92; Dickinson, Judicial Control of Official Discretion, (1928) 22 A2s. POL Scr. REv. 275.

3. The late Professor Freund is a vell-recognized exception to this statement. His studies led him to believe that "the most important point in the development of administrative law is the reduction of discretion." FreUnd, TRE GRowis of Aiserscass Adamistrative Law (1923) 24. But see the reply of Dean Wigmore in 19 In. I. REv. (1925) 440, and the subsequent answer by Professor Freund in (1925) 19 ILL. I. REv. 663. However a careful reading of Freund's articles on discretion leads one to believe that he spoke primarily of the administration in a pure police State rather than a State which must constantly deal with the complexities of the socia! and economic order.

4. There is today a disconcerting tendency on the part of those assuming an interest in the affairs of government to waste their time and efforts by failing to look bahind the symbols which surround most discussions of political problems. The use of such symbolism as well as the failure to recognize the existence of true facts merely serves to obscure fundamental questions which should be openly faced. See Arroco, Srarrous of Governuresi (1935) 199. 
of administrative discretion and the unavoidable necessity for its use in the execution of governmental policies. In other instances the attitude of suspicion toward the exercise of discretion is often based upon an unyielding belief that any function which is not employed in accordance with the traditions of judicial technique or at least under its watchful supervision is inherently dangerous if not completely undesirable. ${ }^{6}$ But more significant than these apparent manifestations of misunderstanding is the increasing disposition of those opposed to governmental interference to use the principle of administrative discretion as a whipping post for the revival of a laissez faire policy. These more or less confusing ideas concerning the problems of administration have done much to eliminate intelligent thinking and careful analysis from most discussions of the more fundamental aspects of administrative functions. This is certainly true with regard to the exercise of administrative discretion.

It will be assumed that governmental administration should and must be considered in the light of the more recent improvements in both its methods and operation. To attempt a study of this nature without realizing that public administration is no longer the completely inefficient and cumbersome instrument of government so characteristic of the nineteenth century is to close one's eyes to the progress which has been made in the last three decades. However, it is not suggested that administration is a perfect, unerring machine or that there does not remain substantial room for improvement in both its technique and accomplishments. But it seems only proper. that a realistic consideration of the role of administrative discretion should proceed within the framework of actual conditions and not by reference to circumstances which no longer find any basis in reality. Due to the fact that the nitional government provides the greatest variety of administrative problems and that federal administration most clearly reveals the sharp conflict with judicial techniques, the following discussion will be limited for the most part to a consideration of administrative discretion in the federal sphere of operation.

\section{The Growth and Nature of Discretion}

Problems of public administration concern the more practical aspects of a government in operation; their solution demands the arcption of methods which will insure an equally practical treatment. This practical approach to administrative problems must first recognize that the nature

5. Compare the refreshingly liberal attitude of Lord Shaw in Local Government Board v. Arlidge [1915] A. C. 120, 138, where he made the following pertinent observation regarding the methods of administration: "But that the judiciary should presume to impose its own methods on administrative or executive officers is a usurpation. And the assumption that the methods of natural justice are cx necessitate those of courts of justice is wholly unfounded." 
and importance of administration can be understood only through an intelligent appreciation of the present responsibilities of modern government. $^{6}$ No function of administration is more urgently in need of such a realistic analysis than the exercise of administrative discretion, i.e., to that end the role of discretion must be considered against a background which reveals a constantly increasing demand for more and more governmental intervention in social and economic areas previously left to private initiative. ${ }^{7}$

The relation between legislative action and administrative responsibility has primarily determined the nature and importance of administrative discretion. Just as the functional aspects of the State have passed through an extended period of development from the law enforcing agency of the Middle Ages to the law exerting agency of the present, so the fundamental characteristics of legislative activity have undergone an evolutionary growth which has profoundly affected the role of governmental administration. During our early political history, and in fact almost until the turn of the century, the national legislature was chiefly concerned with the enactment of laws relating to the more basic necessities of an organized society. In this respect legislative action, or rather the lack of such action, was symptomatic of the simple police State which sought merely to guarantee the individual a maximum of freedom from coercive influences and a protection against the more obvious types of anti-social conduct. With the creation of a highly integrated industrial system which brought forth its own new problems and the subsequent decline of the laissez faire philosophy of government the national legislature was compelled to concern itself more and more with the social and economic welfare of the nation. In succeeding stages over a period of many years, Congress found it necessary to bring within the federal sphere of control, by the enactment of regulatory legislation, the activities of many public utilities, including railroads, telephones, telegraphs, electric power, motor carriers and maritime shipping, private business relations and practices, the establishment of national fiscal and monetary policies, stock market and investment practices, agricultural production and distribution, labor relations, and a variety of serious problems arising out of our complex industrial system. But the mere passage of positive laws bringing these myriad activities under the regulatory power of the federal government was only the first step in the correction of social and economic maladjustments. Laws do not administer themselves -they require an additional force to supervise the execution of the legislative policy. The indispensable concomitant of this expansion of governmental control has been an ever-increasing growth in the responsibilities

6. Herring, Public Aduinistration and the Public Interest (1936) 17.

7. Pfiffier, Pualic Administration (1935) 3-20. 
of public administration. This fact should not be overlooked and can not be emphasized too often. Once a statute has been enacted into law it must be enforced by either or both of the other two branches of our government. The initial application of the law to individual situations rests with the executive branch, but its ultimate interpretation or application in, a particular controversy frequently falls upon the judiciary. During the period when the national legislature was primarily concerned with the perpetuation of an individualistic political philosophy, administration played but a small part in the execution of the legislative will. Laws were largely self-operating in the sense that no particular executive agency was needed to exercise its skill or judgment in the application of the national policy. Some application of the legislative mandate was obviously necessary, but its enforcement was a relatively simple matter and generally a semi-automatic procedure. Congressional acts for the most part were simple in form and related to activities which were easily susceptible of definition as well as control. But as Congress became more and more involved in the problems of social and economic readjustment, the initial administration of its statutes became a serious problem. It was this development in legislative responsibilities which prompted former Dean Pound to observe that "as the eighteenth and the forepart of the nineteenth century relied upon the legislature and the last half of the nineteenth century relied upon the courts, the twentieth century is no less clearly relying upon administration." 8 The evolutionary development of American government has been away from the enactment of generic legislation toward the creation of vast administrative powers to implement the legislative mandate which, of necessity, must be limited to general terms. This shifting of emphasis from legislation to administration is nowhere more clearly exemplified than by the changing character of our public utility regulation.

There are several practical reasons why Congress has been compelled to create administrative agencies for the execution and enforcement of its expressed policies. ${ }^{\circ}$ And there are likewise sound reasons why these agencies have been entrusted with a discretionary authority to administer the provisions of many legislative acts. In the first place, Congress could not possibly enact into a single body of law the infinite details necessary to completely define the national policy involved in the

8. Pound, The Administrative Application of Legal Standards (1919) 44 A. B. A. REPORT 445, 446.

9. "Administrative tribunals... did not come because any one wanted them to come. They came because there seemed to be no other practical way of carrying on the affairs of government and discharging the duties and obligations which an increasingly complex social organization made it necessary for the government to perform . . ." Rosenberry, Administrative Law and the Constitution (1929) 23 AM. PoL. Scr. Rev. 32, 35 . 
control and solution of many social or economic problems. Consequently, it was necessary to establish a standard or policy in general statutory language and entrust its enforcement to an agency created for that purpose. In the second place, Congress possesses neither the scientific linowledge nor the technical competence to define completely the national policy in many of its more complicated aspects. The establishment of the Securities and Exchange Commission was largely due to the inability of Congress to provide lasting solutions for the intricate problems arising in connection with the regulation of stock market and investment practices. In the third place, since Congress remains in session only intermittently, it could not possibly exercise the continuing supervisory power so frequently necessary to the complete effectuation of legislation policies. When new fields of regulatory control are entered by legislative action, careful experimentation is indispensable to the solution of unforeseen difficulties which are constantly arising in connection with the enforcement of general statutes. The establishment of administrative agencies has provided an effective instrument to exercise this power of supervision which is at once informed by training and experience and in constant contact with the problems of enforcement or administration. The $\mathrm{Na}$ tional Labor Relations Board was created to exercise this sort of supervision in connection with the formulation of a national labor policy.

The same inherent deficiencies which have prevented legislative bodies from enacting a complete scheme of statutory regulation and from exercising a constant supervision over the enforcement of their general policies require the delegation of power and authority to perform these necessary functions. The answer to this need was discovered to be the creation of effective instruments of control endowed with a limited discretion to administer the general terms of the legislative mandate. Just as the legislative body is endowed with a broad discretionary power to select a variety of policies in the enactment of its laws, so the administrative tribunal must be similarly entrusted with a discretionary authority to enforce the statute in such a way as to produce the result sought by the legislature. ${ }^{10}$ By the term "discretion" is meant the liberty of choosing between possible alternatives. ${ }^{11}$ Administrative discretion is the freedom of choice or judgment with which an executive officer or an administrative agency is entrusted in order to insure the constant and complete effectuation of the legislative policy in any situation which might arise in connection with the enforcement of the statute.

To guide and limit the administrative agency in the exercise of its lawful authority the legislature establishes a criterion or standard of

10. This distinction was pointed out and approved in Cincinnati, Wilmington, ete. RR. v. Commissioners, 1 Ohio St. 77, 88 (1852).

11. Dimock, The Role of Discretion, in Fiontiens of PUDLic Anumnsmanton (1936) $45,46$. 
action within the terms of the statute itself. This common practice has resulted in the enactment of what has been described as skeleton legislation, which perhaps reached its most extreme form in the enactment of the National Industrial Recovery Act. The types of discretionary authority conferred by Congress upon administrative agencies and the standards utilized to guide administrative action are as varied as the classes of activities or transactions that are sought to be brought under federal control. ${ }^{12}$ In light of the factors which have given rise to the creation and growth of administrative tribunals, a few examples of such legislative standards which measure the area of administrative discretion should suffice to demonstrate the compelling soundness of these delegations of authority. The Act to Regulate Commerce authorizes the Interstate Commerce Commission to consider such complex standards in the administration of the statute as "reasonable rates," "public convenience and necessity," "undue preference" and "unreasonable discrimination." The Federal Communications Commission must consider similar concepts and in addition such other standards as "action necessary or desirable in the public interest," "adequate facilities and services," "undue or unreasonable disadvantage" and "public convenience, interest, or necessity." The Securities and Exchange Commission is required to apply such concepts as information necessary for "protection of investors," "maintenance of a fair and orderly market," "reasonable rates of commission" and "manipulative or deceptive devices" in the enforcement of its statute. In the administration of the Federal Trade Commission Act that body is guided by such standards as "unfair methods of competition," "discrimination in prices" and stock acquisitions which "tend to create a monopoly." In the field of industrial conflicts the National Labor Relations Board is required to interpret and apply such concepts as "collective bargaining," "discrimination in regard to hire or tenure of employment" and "unfair labor practices" which "interfere with, restrain, or coerce employees" or "dominate or interfere with any labor organization." This list of legislative standards could be extended indefinitely, but these few examples will serve to indicate the complexity of the regulatory problems which arise in connection with the enforcement of a specific national policy.

It would seem to be beyond all reasonable argument that Congress could, under any circumstances, adequately define such concepts to the

12. Professor Dimock has suggested that there exist various levels of discretion which may be classified as routine, emergency, control and social-conflict situations. He observes concerning the delegation of discretionary authority that it "does not always assume the same external appearance nor is it equally essential in all realms of administration. Its raison d'etre varies in degree, depending upon the object of the act and the nature of the administrative duty $\therefore$. But just as discretion is common to all departments of government, so is it found in all forms of administrative activity." Id., at 50, 51. 
extent that the exercise of judgment and discretion by administrative agencies would no longer be desirable or necessary. But the application as well as the interpretation of these legislative standards to particular situations in connection with the administration of the respective statutes requires the exercise of specialized knowledge and technical judgment seldom possessed by legislative bodies. The administration of general legislation by technical experts, skilled and trained in specialized fields, is "the contemporary answer to the challenge to bridge the gap between popular government and scientific government." 13 When these standards of action are set up in statutory form the legislature seldom takes the trouble to indicate in express terms that it intends the administrative agency to have a discretionary authority to administer such concepts. Yet it is obvious that this is the actual intent of the legislative body. In many instances these legislative standards have come to have a meaning which inheres in the terms themselves. However, this crystallization of meaning is usually accomplished only after an extended period of experimentation and administrative interpretation. ${ }^{14}$ In other instances the content of such standards has a meaning only when related to the general policy of the particular legislative enactment. ${ }^{15}$ But regardless of the sources which the administrative agency draws upon in its duty to apply the standards of action in concrete situations, varying degrees of discretion are necessary to accomplish the purposes sought by the legislative mandate. The practical result of the creation of these specialized tribunals endowed with a discretionary authority is the development of a competence that expresses "an intuition of experience which outruns analysis and sums up many unnamed and tangled impressions; impressions which may lie beneath consciousness without losing. their worth." 16

The transmission of governmental policy from its source to the point where it is finally applied in the form of an enforceable determination frequently demands the exercise of two correlative administrative functions, both of which arise from the discretionary authority vested in the administrative agency. ${ }^{17}$ On the one hand these tribunals are constantly engaged in the promulgation of general rules and regulations concerning the various matters within their respective jurisdictions. This function

13. Dickinson, supra note 2 , at 277 .

14. The standard of reasonable rates is a concept which has come to have a crystallized meaning due largely to judicial interpretation of the due process clause of the Fourteenth Amendment.

15. An obvious example of such a standard is the "public interest" which must of necessity vary with the legislative purpose.

16. Mr. Justice Holmes in Chicago, B. \& Q. Ry. v. Babeocl, 204 U. S. 585, 593 (1907). See Fuchs, Concepts and Policies in Anglo-Americon Admiristrotive Low Theory, (1938) 47 YALE L. J. 538, at 546.

17. See id., at 545 . 
has been described as an administrative legislation, since its exercise involves the implementation of statutes by laying down general rules for the future action of the agency in question. ${ }^{18}$ On the other hand these agencies are also compelled to make many decisions applying the basic law or the rules promulgated thereunder to specific situations in which a controversy has arisen. The settlement of disputes between the administrative agency and the party against whom an order is about to be issued has been described as administrative adjudication, since it resembles, in certain minor respects, the exercise of a judicial power. Although the line of demarcation between these functions is at times none too clear, the theoretical distinction suggested is nevertheless worthy of observation. ${ }^{19}$ There has been some suggestion that the function of administrative legislation should be segregated from the adjudicative processes and vested in a separate tribunal in order to avoid the commingling of such powers. ${ }^{20}$ But it seems clear that the process of administration is one which must be viewed as a whole, and its functions are not susceptible of segregation in accordance with a few general characteristics. ${ }^{21}$ Despite their distinguishing features these functions are in a real sense integral and dependent parts of the same administrative process mutually interwoven by the practical necessity of preserving administrative autonomy. The proposal to segregate these functions would undoubtedly impair the efficiency and speed of governmental administration and tend to disrupt the entire administrative process during its latter stages. In so far as constitutional limitations are concerned, the doctrine of separation of powers has never been interpreted by the

18. See Hart, The Exercise of the Rule-Making Power, in Studies on Adsunistrattve Management in tre Governuent of the United States, The Presidenst's Comarittee on Administrative Management (1937) No. 5.

19. For an exhaustive analysis of the character and nature of administrative func: tions, see Blachly \& Oatmin, Adusinistrattve Legislation and Adjudication (1934).

20. See the Report of the Spectal Comamtitee on Adurinistrative Law of rute Amprican Bar Assoctation (1936) 61 A. B. A. Report 720. For a criticism of the Logan Bill which embodied this proposal see my article on the subject. The Proposed Administrative Coúrt, (1937) 35 Mice. L. REv. 193, 565, 566.

21. In a speech given before the Judicial Section of the American Bar Association, in Los Angeles on July 16, 1935, John Dickinson, former Assistant Attorney General of the United States, disapproved a similar proposal for the segregation of the adjudicative functions of administration. In that connection Mr. Dickinson said: "The agency which makes inspections; collects information, supervises accounts, interprets the statute, must be the same agency which makes, at least in the first instance, the quasi-judicial determinations of approval or disapproval of applications for grants and permits, and the quasi-judicial orders to conform or desist from certain conduct. I do not see how these quasi-judicial functions can be torn from the executive or administrative agency without leaving more than a crippled torso behind." 
courts to prohibit this blending of administrative powers. ${ }^{22}$ If we are to have a competent scientific administrative government, the discretionary authority entrusted to its instrumentalities must be exercised in accordance with the objectives of the expressed legislative policy free from the restraining influences of strict constitutionalism. ${ }^{23}$

.Quite apart from the question of judicial review, which will be considered subsequently, there are other fundamental safeguards which limit both the legislature and the agencies of administration in the delegation of discretion. It was previously stated that the doctrine of separation of powers has never been interpreted to prevent administrative tribunals from exercising all of their necessary functions regardless of how closely they may seem to resemble the powers utilized by the other branches of the government. However, a corollary of this doctrine, delegata potestas non potest delegari, has received a more restrictive construction by the courts. This latter doctrine prohibits any of the three branches of the government from abdicating or transferring to another branch the essential functions with which they are vested by the Constitution. And it is this constitutional maxim which has served as a check on the unwarranted delegation of authority by the legislature and curtailed the degree of discretion with which administrative agencies may be endowed. To avoid the restrictions of this doctrine Congress is compelled to limit the breadth of administrative action by laying down policies and establishing standards of action in its delegation of discretionary authority. The purpose of the establishment of these standards is to canalize the exercise of discretion within the objectives and purposes of the legislative enactment. Although there is no objection to the practice of entrusting the instrumentalities of administration with a discretionary authority to insure the complete effectuation of the legislative policy, the authority conferred by the legislature must include the establishment of a criterion to prevent the arbitrary or capricious exercise

22. Brinkley v. Hassig, 83 F. (2d) 351 (C. C. A. 10th, 1936); Farmers' Livestod: Commission Co. v. United States, 54 F. (2d) 375, 381 (D. C. III. 1931). Recently the Supreme Court denied a petition for a writ of certiorari in a case which directly raised the question of the constitutional validity of the blended powers in the Federal Trade Commission. MIcLean \& Son v. Federal Trade Commission, 299 U. S. 590 (1936).

23. "There is an undoubted trend to enlarge the power of the executive branch by a gradual delegation to it of mixed powers-partly legislative and partly judicial . . We found of late years that the sharp distinction of three departments might be suitable for our country in the early days; but as the conditions and need for their control became more complicated and novel, we realized that no one distinct department could deal with them alone ... Instead of adhering to the old distinction, vie bowed to necessity; and when the constitutional right to do this was challenged we had the letter of the Constitution yield to the spirit of the demand." Nagel, Federal Defartmental Practice, in The Growtr of Azrerscan Ademsistratuve Lav (1923) 175, $177-178$. 
of such discretion. To state the proposition more succinctly, administrative agencies may be endowed with a discretion as to the execution of a law, but they cannot be entrusted with the power to make laws. ${ }^{24}$

Until quite recently the courts had consistently sustained broad delegations of authority by Congress to executive or administrative officials in recognition of "the necessity of adapting legislation to complex conditions involving a host of details with which the national legislature can not deal directly." 25 In most of these cases the degree of discretion vested in the administrative official was as broad as the situation demanded, and the courts had little difficulty in finding a standard of action within the terms of the particular statute. ${ }^{26}$ However, in two recent cases the Ryan and Schechter cases - the Supreme Court took a somewhat different position and held that the authority which Congress had attempted to delegate to the President did not include the basic standards necessary to guide him in the exercise of the discretion conferred by the statutes. ${ }^{27}$ For this reason the delegations of authority were declared to be without practical limitation and thus unconstitutional. In view of these pronouncements it seems clear that although Congress may invest administrative agencies with a discretionary authority to carry out the legislative mandate within the limits prescribed by the statute, "the constant recognition of the necessity and validity of such provisions, and the wide range of administrative authority which has been developed by means of them, can not be allowed to obscure the limitations of the authority to delegate, if our constitutional system is to be maintained." ${ }^{28}$

In order to make the doctrine of non-delegability of powers a more effective principle and to guarantee protection from the arbitrary or capricious exercise of discretionary authority the Court has indicated the necessity of imposing a further safeguard. This requirement, however, falls upon administration itself rather than upon the legislature and serves to reinforce the limitations established by the legislative standard. In the Ryan case the Court not only demanded the establishment of a legislative standard to canalize administrative action, but held that express findings by the administrative authority "as to the existence

24. Field v. Clark, 143 U. S. 649, 692 (1892).

25. Schechter Corp. v. United States, 295 U. S. 495, 529-530 (1935).

26. The Brig Aurora, 7 Cranch (U. S. 1813) 382; Field v. Clark, 143 U. S. 649 (1892); Buttfield v. Stranahan, 192 U. S. 470 (1904); Union Bridge Co. v. United States, 204 U. S. 364 (1907); Monongahela Bridge Co. v. United States, 216 U. S. 177 (1910); United States v. Grimaud, 220 U. S. 506 (1910); Red "C' Oil Co. v. North Carolina, 222 U. S. 380 (1911); Avent v. United States, 266 U. S. 127 (1924) ; Central Securities Corp. v. United States, 287 U. S. 12 (1932) ; Hampton \& Co. v. United States, 276 U. S. 394 (1928).

27. Panama Refining Co. v. Ryan, 293 U. S. 388 (1935); Schechter Corp. v. United States, 295 U. S. 495 (1935.).

28. Panama Refining Co. v. Ryan, 293 U. S. 388, 421 (1935). 
of the required basis of . . - action would be necessary to sustain that action, for otherwise the case would still be one of an unfettered discretion . . ."29 Thus, in accordance with the Court's interpretation of the doctrine the legislature must establish a basic standard in its delegation of authority to an administrative agency, and the agency in turn must make an express finding to indicate that it is açting within the limits set by the legislature in the exercise of the authority conferred. ${ }^{30}$ This further limitation on the exercise of discretion is of doubtful utility as a practical safeguard against the abuses of authority since its requirements can usually be met by merely reciting rather vague language concerning the legislative standard. ${ }^{31}$ However, in the past many administrative agencies have made a practice of including such findings in their decisions, and there is considerable evidence that such a procedure is of some assistance to courts reviewing the validity of such action. ${ }^{32}$ In any event, it does not appear that the requirement would hamper or impair the orderly process of administration in its exercise of discretionary authority.

The preceding discussion was undertaken to present a clear picture of the nature and importance of administrative discretion. Such an analysis should demonstrate that there is nothing mysterious or sinister in the recent tendency to endow administrative agencies with such discretionary authority. The growth of these administrative powers was logical, necessary, and unavoidable. The legislature found itself incapable of assuming the responsibilities necessary to insure the complete effectuation of its policies. The duty of administering the general provisions of these legislative enactments was thus entrusted to selected instrumentalities which were authorized to fill up the details of the statutes and ascertain the facts to which the law is directed. To this end administrative agencies were entrusted with a discretionary authority to translate the general standard into an effective determination in any situation involving the application or interpretation of the legislative policy. In this respect and

29. Id., at 431.

30. See The Chicago Junction Case, 264 U. S. 258, 263 (1924); United States v. Atlanta, B. \& C. R. Co., 282 U. S. 522,527 (1931); Florida v. United States, 282 U. S. 194, 215 (1931); United States v. Baltimore \& Ohio R. Co., 293 U. S. 454, 462 (1935).

31. E.g., an order of the Interstate Commerce Commission was set aside merely because that body did not make an express finding, after extensive hearings, that steam locomotives "equipped with hand reverse gear as compared with power reverse gear causes unnecessary peril to life or limb" despite the fact that all the evidence pointed to such a conclusion. See United States v. Baltimore \& Ohio R. Co., 293 U. S. 454, 462 (1935); Feller, Prospectus for the Further Study of Federal Administralive Low, (1938) 47 YALE I. J. 647, 665.

32. The Federal Equity Rules (701/2) require the District Courts to mal:e similar, although perhaps more extensive, findings of fact in cases coming before them. 
from a functional. standpoint administrative discretion is the life blood upon which the entire administrative process feeds; without its vitalizing contribution the machinery of administration would degenerate into an impotent force with neither purpose nor direction. In a certain sense the recent tendency to invest administrative agencies with a discretionary authority is a belated recognition of the paramountcy of the public over private interests. To this extent the principles of public law repudiate the older theory that administrative justice must be meted out in accordance with the traditions of the common law, for in view of the present responsibilities of the modern State the rights and interests of the private citizen can no longer be placed above or on an equal basis with the privileges and interests of government. The sound exercise of discretionary authority is the answer to the demand that administration be accorded a freedom to determine what the national interest requires in any situation within its control.

\section{The Control of Discretion}

Discussions concerning the scope of judicial control over administrative determinations comprise the major part of the legal literature in the administrative law field. ${ }^{33} \mathrm{~A}$ comprehensive analysis of the existing rules of review would fall beyond the narrow limits of this study. However, it will be necessary to examine, in a general way, some of the more important judicial decisions which have served to guide the courts in the performance of their traditional duties as the self-appointed supervisors of the governmental process.

It must be admitted at the outset that some measure of control over administrative action is necessary to protect private rights from arbitrary and unlawful interference. And similarly it must be conceded that certain aspects of this control have been properly committed to the judiciary. The more difficult problem arises in connection with a determination as to how far the courts should be permitted to extend their control in reviewing the validity of administrative action. The need for a formula to define adequately the areas of administrative immunity and judicial supervision is one of the most pressing problems facing government today. Although there is an unmistakable legislative tendency to recognize the basic autonomy of administration, ${ }^{34}$ there is still much to be desired in the way of a satisfactory balance between free administrative action and the utilization of traditional legal safeguards. In analyzing the elaborate set of rules relating to the scope of review which the courts

33. See the voluminous material on this subject cited in Black, The "Jurisdictional Fact" Theory and Administrative Finality, (1937) 22 CoRN. L. Q. 349, 515.

34. For a thorough study of the recent tendency to immunize administrative determinations see Dickinson, The Conclusiveness of Administrative Fact-Determinations Since the Ben Avon Case (1935) 16 P. U. ForT. 385. 
have established by piecemeal adjudication, it is important to understand what the courts do in particular cases as well as what they say. Furthermore, since these rules are largely self-imposed by the judiciary itself, ${ }^{35}$ it is also necessary to recognize the many exceptions to the general rules that have been created by reference to nice technical distinctions in order to enable the court to exercise whatever control it deems necessary in the particular case.

With the exceptions of earlier decisions relating to the use of traditional common law remedies, ${ }^{38}$ the courts have only on rare occasions delimited their power of review solely because the authority conferred upon the administrative agency was discretionary in character. The judiciary has seldom concerned itself with the character of the administrative function which it seeks to supervise. As a general proposition the courts have held in numierous cases that the determinations of an administrative agency are final and conclusive unless arbitrary, capricious, or not based upon substantial evidence. ${ }^{37}$ In adopting this principle the Supreme Court has said that the judiciary "will not consider the expediency or wisdom of the order, or whether, on like testimony, it would have made a similar ruling." ${ }^{38}$ On an earlier occasion that Court had indicated that the orders of the Interstate Commerce Commission would be reviewed only for the purpose of determining whether or not (a) they were repugnant to the Constitution, (b) they were within the scope of the authority conferred by statute, and (c) the agency had acted in an arbitrary or unreasonable manner. ${ }^{39}$ And this same doctrine was restated in later cases relating to the determinations of various other administrative agencies. Commencing with these fundamentally sound principles, the courts have gradually developed a confusing mass of technical distinctions which have seriously reduced the area of administrative autonomy and enabled them to extend their power of review almost without practical limitation.

The most persistent distinction that appears in both the decisions and the many legal treatises on the subject is the classification of admin-

35. Davison, Administration and Judicial Self-Limitotion (1936) 4 GEo. Wasm. L REv. 291.

36. Decatur v. Paulding, 14 Pet. 497 (U. S. 1840); Reeside v. Wallice, 11 How. 272 (U. S. 1850); Dunlap v. Black, 128 U. S. 40 (1889); United States v. Blaine, 139 U. S. 306 (1891) ; United States v. Hitchcock, 190 U. S. 316 (1903) ; Greenameyer v. Coate, 212 U. S. 434 (1909).

37. Interstate Commerce Commission v. Union Pacific Ry., 222 U. S. 541 (1912); Manufacturers Ry. v. United States, 246 U. S. 457 (1918); Virginia Ry. v. United States, 272 U. S. 658 (1926); Bates \& Guild Co. v. Payne, 194 U. S. 105 (1904); Morgan v. United States, 298 U. S. 468, 477 (1936).

38. Interstate Commerce Commission v. Union Pacific Ry, 222 U. S. 541, 547 (1912).

39. Interstate Commerce Commission v. Ill. Central Ry, 215 U. S. 452 (1910). 
istrative determinations as "questions of fact" and "matters of law." The analogy of the division of duties between the judge and jury in civil litigation was "taken over into administrative law and applied to the division of function between courts and administrative agencies." 10 In developing this distinction the courts have held that if the administrative action is based upon a pure question of fact, it will not be set aside as long as there is substantial evidence to support the finding. ${ }^{12}$ If, on the other hand, the administrative determination is construed to be based upon an issue of law, the entire proceeding will be reviewed, and the court will exercise its own independent judgment as to the validity of the conclusions reached by the tribunal involved. ${ }^{42}$ This classification of administrative determinations into questions of fact and matters of law has been subjected to withering criticism, ${ }^{43}$ and it is doubtful if the distinction has served any useful purpose other than to indicate the complete irrationality of the courts' explanation as to their duty with respect to the control of administration. ${ }^{44}$ To a certain degree the courts have conceded the inappropriateness of the law-fact classification to many administrative determinations by recognizing the existence of a third category which has been designated as "mixed questions of law and fact." 45 But this further classification has only served to introduce $a$ new complexity since the courts immediately asserted the right to subject these mixed questions to the same complete judicial review as those matters which were said to involve pure issues of law. ${ }^{16}$

40. McFarland, Judicial Control of the Federat. Trade Comuission and Interstate Comarerce Commission (1933) 25.

41. United States v. Louisville \& Nashville Ry, 235 U. S. 314 (1914); Georgia Public Service Commission v. United States, 283 U. S. 765, 775 (1931); Swayne \& Hoyt, Ltd. v. United States, 300 U. S. 297 (1937); Acker v. United States, 298 U. S. 426,434 (1936).

42. Atchison, T. \& S. F. Ry, et al. v. United States, 295 U. S. 193, 201-202 (1935); New England Divisions Case, 261 U. S. 184, 203 (1923); United States v. Abilene \& Southern Ry., 265 U. S. 274, 285-290 (1924).

43. "The delusive simplicity of the distinction between questions of law and questions of fact has been found a will-of-the-wisp by travellers approaching it from several directions." Isaacs, The Law and the Facts, (1922) 22 CoL. L. Rev. 1. Sce also Dickinson, Administrative Justice and Supreasacy of the LAw (1927) 49;

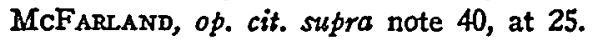

44. "Matters of law grow downward into roots of fact, and matters of lact reach upward, without a break, into matters of law. The knife of policy alone effects an artificial cleavage at the point where the court chooses to draw the line between public interest and private right. It would seem that when the courts are unwilling to review, they are tempted to explain by the easy device of calling the question one of 'fact' .. " Dickinson, op. cit. supra note 43, at 55. See also Clark and Stone, Review of Findings of Fact (1937) 4 UNIr. of CHr. L. Rev. 190, for an excellent critique of the subject as it relates to the lower federal courts.

45. Bates \& Guild Co. v. Payne, -194 U. S. 106 (1904).

46. United States v. Idaho, 298 U. S. 105 (1936); Interstate Commerce Commission v. Union Pacific Ry., 222 U. S. 541 (1912); St. Joseph Stock Yards Co. v. 
Still other judicial distinctions have enabled the courts to develop inroads on the basic principle that administrative fact determinations are generally final and conclusive. The doctrine of constitutional or jurisdictional fact determinations is the basis of another technical classification with respect to which the reviewing court must exercise its own independent judgment as to the validity of the administrative ruling. Regarding such determinations the Supreme Court has said that "the final determination of the existence of facts upon which the enforcement of the constitutional rights of the citizen depend" cannot be committed to an administrative agency. ${ }^{47}$ Thus, it would appear that wherever an administrative ruling is attacked on the ground that it violates the constitutional rights of the party against whom the determination was made, the reviewing court must reach its own independent judgment as to the validity of such administrative action. ${ }^{48}$ Similarly, the Court has held that this broad scope of review applies to all fact determinations which relate to the jurisdictional authority of the administrative agency, ${ }^{40}$ since these determinations are said to be fundamental in the sense that their existence is a condition precedent to the operation of the statutory scheme. $^{50}$ Consequently, it has been held that when the administrative agency makes a finding, regardless of whether it is purely factual or not; which incidentally involves a determination of its jurisdiction over a particular subject matter or transaction, that determination must remain open to the independent judicial review by the trial court. In deference to this doctrine the Supreme Court has apparently denied to administrative agencies the right to determine the extent of their statutory jurisdiction, although it has accorded that right to judicial tribunals in the past." In that connection the Court has said while "it is true that there may be a [judicial] jurisdiction to determine the possession of jurisdiction $^{52}$. . . the full doctrine of that case cannot be extended to administrative officers." 63

United States, 298 U. S. 38, 74 (1936). But compare: "Where there is a mixed question of law and fact, and the court cannot so separate it as to show clearly where the mistake of law is, the decision of the tribunal to which the law has confided the matter is conclusive." Bates \& Guild Co. v. Payne, 194 U. S. 106, 109 (1904).

47. Crowell v. Benson, 285 U. S. 22, 56 (1932). Seé Landis, Adminisiralize Policies and the Courts (1938) 47 Y YIE L. J. 519, at 523 ff.; Fuchs, supra note 16, at $563 \mathrm{fF}$.

48. Ohio Valley Water Co. v. Ben Avon Borough, 253 U. S. 287, 289 (1920); Crowell v. Benson, 285 U. S. 22 (1932) ; St. Joseph Stock Yards Co. v. United States, 298 U. S. 38, 44 (1936).

49. United States v. Idaho, 298 U. S. 105 (1936); Piedmont \& Northern Ry. v. Interstate Commerce Commission, 286 U. S. 299 (1932); United States v. Chicago, North Shore \& Milwaukee Ry., 288 U. S. 1 (1933).

50. Crowell v. Benson, 285 U. S. 22 (1932). See Landis, supra note 47, at 523.

51. Ex parte Harding, 219 U. S. 363 (1911).

52. Citing Ex parte Harding, 219 U. S. 363 (1911).

53. Humbolt Steamship Co. v. Interstate Commerce Commission, 224 U. S. 474, 484 (1912). 
Still another but more drastic principle has been developed by the courts to supplement the distinctions which lie at the foundation of the requirement that certain determinations must be left open for independent judicial scrutiny: If it be assumed that the reviewing court must determine for itself the existence of constitutional or jurisdictional facts, upon what record is the independent determination to be made? The Supreme Court has answered this question by holding that as to these fundamental matters a complete trial de novo must be available to litigants in order that the Court may "determine such an issue upon its own record and the facts elicited before it." is In other words, the judiciary is not satisfied with merely supervising the administrative proceeding but requires a complete retrial of the issues which it believes to be fundamental. With respect to these basic determinations, the question is not whether the administrative official "has acted improperly or arbitrarily as shown by the record of his proceedings in the course of administration in cases contemplated by the statute, but whether he has acted in a case to which the statute is inapplicable." ${ }^{\circ 5}$ This conclusion was reached by the Court despite its previous statements that "correct practice requires that, in ordinary cases, and where the opportunity is open, all pertinent evidence shall be submitted in the first instance to the" administrative agency ${ }^{58}$. and that where a determination is claimed to

54. Crowell v. Benson and St. Joseph Stock Yards Co. v. United States, both cited sipra note 48.

55. Crowell v. Benson, 285 U. S. 22, 63 (1932). An interesting situation has arisen in connection with the enforcement of the National Railway Labor Act. Although the administration of that Act is delegated to both the National Railroad Adjustment Board and the National Mediation Board, the Interstate Commerce Commission has been given a special statutory jurisdiction to determine whether a particular carrier is a "street, interurban or suburban electric railway" within the exemption proviso of the Act. Upon the request of the Mediation Board the Commission considered the status of the Utah Idaho Central Railroad Company and determined that it was not an interurban electric railway within the exemption proviso. From this determination the railroad appealed to the courts, claiming that the court must exercise its own independent judgment as to the validity of the Commission's conclusion since the issue involved was one of jurisdictional fact. Dan B: Shields, et al. v. The Utah Idaho Central Ry., Equity No. 12924 (Dist. Ct. Dist. Utah, 1936). The Government argued that this was not a case of jurisdictional fact since Congress had authorized the Commission to make a determination on that single issue rather than the Mediation Board whose jurisdiction was directly involved. The court overruled the Government and reached its own independent judgment as to the validity of the administrative determination. The case has been appealed to the Circuit Court of Appeals. Equity No. 1558 (1937) C. C. A. 10th. It raises the interesting question as to whether the jurisdictional fact doctrine can be avoided by transferring jurisdictional determinations to separate administrative agencies.

56. Manufacturers' Ry. v. Interstate Commerce Commission, 246 U. S. 457, 489 (1918). See also Mississippi Valley Barge Co. v. United States, 292 U. S. 282, 286 (1934); Town of Inlet v. New York Central R. Co., 7 F. Supp. 781, 784 (N. D. N. Y. 1934). 
be invalid due to the discovery of new evidence "the appropriate remedy is to apply for a rehearing . . . or to institute new proceedings." formulating these technical distinctions between ordinary facts and "fundamental" or "jurisdictional" facts, the judiciary has succeeded not only in converting the administrative body into "a mere instrument for the purpose of taking testimony to be submitted to the courts for their ultimate action," ${ }^{58}$ but also in reserving to itself the "questionable privilege of completely ignoring the prior administrative proceedings regardless of how extensive or complete they may have been. ${ }^{\text {E9 }}$

This brief analysis of the existing scope of judicial review ${ }^{60}$ reveals at least two interesting points that are worthy of critical examination in their relation to the control of administrative discretion. The first point to be noted - which apparently lies at the foundation of the many technical distinctions described above - is the inevitable attitude of the courts with respect to the superiority of traditional legal techniques and the suggested "difference in security of judicial over administrative process." ${ }^{81}$ This attitude may be succinctly described as the presumption of judicial infallibility. The second point to be observed is the consistent development of technical distinctions to enable the courts to exercise a more and more comprehensive control over administration in utter disregard of the unique character of discretion. In short, by the use of these artificial distinctions the judiciary has sought to supervise the exercise of discretionary authority regardless of its competency to handle or solve the technical problems of .governmental administration. Although the

57. Tagg Bros. \& Mioorhead v. United States, 280 U. S. 420,445 (1930).

58. United States v. Louisville \& Nashville Ry., 235 U. S. 314, 321 (1914).

59. See the vigorous dissent by Mr. Justice Brandeis in Crowell v. Benson, and a similarly critical concurring opinion in St. Joseph Stock Yards Co. v. United States both cited supra note 48. See also Dickinson, Judicial Review of Administralize Detcrminations of Questions of "Constitutional Fact" (1932) 80 U:rv. OF PA. L. REv. 1055; Comment (1937) 25 Cat. L. Rev. 315.

60 . The courts have also evolved other distinctions based primurily upon the type of controversy which they are requested to review. These theories, however, have baen used to restrict rather than to enlarge the existing scope of review. One of these theories recognizes the impropriety of permitting private litigants to question the determinations of administrative officers in situations where the government is extending a privilege or gratuity to the members of the public. See Freund, Anzrmistuntive Powers Over Persorss and Property (1928) c 15 . Another theory recognizes the importance of the efficient performance of indispensable governmental services and functions with a minimum of interference from private parties, whose interest in such matters is at the most indirect. And as a corollary to this theory, the courts also recognize that where governmental functions are being performed in the exercise of sovercign powers and involve grave questions of policy or of a political nature, the adjudieations of executive officials should not be disturbed by judicial re-examination at the instance of private citizens whose interests play but a small part in the formulation of national policies. See Dickinson, op. cit. supra note 43, at 59,305 et seq.

61. Crowell v. Benson, 285 U. S. 22, 61 (1932). 
first point is somewhat beyond the scope of this discussion, its importance as the basis for a liberal theory of review justifies at least a cursory examination of the alleged claims of judicial superiority.

This attitude of judicial infallibility is the result of two very questionable assumptions. In the first place, the liberal review theory assumes that there are certain definite findings of fact ascertainable in any proceeding involving the adjudication of private rights which, in reality, are correct, and that any other findings would be erroneous. For lack of a more concise description, this may be termed the assumption of the existence of facts in the absolute. ${ }^{62}$ The fallacy in this position is readily apparent. When a tribunal is created to perform certain governmental functions in accordance with established policies and is authorized to act under stipulated conditions, the absolute existence of facts indicating the presence of such conditions is immaterial so far as the authority of that agency is concerned. The validity of administrative action depends upon the facts as found by the adjudicating agency in a regularly conducted procceding for that purpose. ${ }^{63}$ The absolute existence of these or other facts in reality should have no bearing on the authority of the agency or the validity of its determination, provided there were no substantial irregularities in the administrative proceeding. ${ }^{61}$ A system of administrative justice which fails to recognize this truism contains the seeds of its own destruction. Unless there is accorded a finality to findings of fact at some stage in a proceeding - regardless of their existence in reality - the process of determination and redetermination will never cease. In this respect fallibility is inherent in the fact-finding machinery of any tribunal, whether administrative or judicial. If it be conceded, as it must, that finality must be accorded at some point, the only remaining question concerns the stage of the process of governmental administration at which this conclusiveness should be given. In terms of the present system of administrative justice, the problem centers

62: For a comprehensive analysis and criticism of the jurisdictional fact doctrine, see Gordon, The Relation of Facts to Jurisdiction (1929) 45 L. Q. REv. 459.

63. "The doctrine of jurisdictional fact thus opened the door to the unduly broad review which had been foreclosed by the original doctrine that the exercise of administrative discretion was protected by judicial immunity. It had the further disadvantage of leaving always to the courts to determine what facts were jurisdictional . . . The doctrine of jurisdictional fact is the most unfortunate heritage from the older type of indirect review to the newer types of direct appellate review." Dickinson, supra note 2 , at 295.

64. Science and logic have totally failed to provide us with tools by which we may ascertain the absolute existence of any state of facts. At best ve can mercly approximate truth. In the conduct of judicial determination this fallibility is immeasurably increased by the abstract nature of legal proof. As Mr. Justice Brandeis observed in Crowell v. Benson, 285 U. S. 22, 85 (1932), the exercise of a delegated authority to an administrative agency cannot "depend upon the absolute existence in reality of any fact" since no such absolute determination can be made by any tribunal. 
around the selection of the most suitable tribunal to entrust with this jurisdiction of finality. A consideration of this question involves an analysis of the second assumption inplicit in the liberal review theory.

This other assumption supporting the doctrine of judicial infallibility strikes at the very heart of administrative integrity. The advocates of the doctrine are presumably of the opinion that an independent tribunal endowed with the antiquated or cumbersome methods of legal procedure, steeped in the traditions of the common law and completely isolated from the previous steps in the administrative process, is the most suitable agency to determine finally the existence of certain basic facts pertaining to an administrative controversy. No adequate reason has ever been advanced to explain why judges, apart from their individual capacities, are the "only suitable custodians of administrative honor and decorum" or "by what strange process . . . judges become more trustworthy than" administrative officials. ${ }^{05}$ It is hardly reasonable to assume that a judiciary, completely untrained in the problems of fublic administration, is more capable or more likely to reach proper results than experienced administrators selected primarily for their specialized knuwledge, technical competence, and thorough familiarity with the intricacies of modern governmental policies. ${ }^{\text {Co }}$ In recognition of this truth the tendency of legislative practice has been in the direction of according greater administrative finality to official action. Within the sphere of legitimate governmental functions, positive administrative adjudication constantly tends to replace the wholly negative aspects of judicial control. And it is noteworthy that a few of the more enlightened nembers of the judiciary are frank in their recognition of the judicial inability to supervise effectively the specialized tasks of administration. ${ }^{\text {bi }}$ This incapacity of the judiciary effectively to supervise or control the processes of administration is nowhere more apparent than in those instances where the administrative agency renders a determination in the exercise of its discretionary authority. ${ }^{68}$ A consideration of this matter brings us to

65. Dimock, Forms of Control Ozer Administratize Aitim, in HaIses A:id Dnsoce, Essays ox the Law axd Practice of Gorerisental .idsusistintio: (1035) 287, 297.

66. The realistic discussions of Jerome Frank and Proiessors Amold and Robinson have done much to dispel the aura of superiority which frequently surrounds the practice and procedure of judicial tribunals. See FraNk, LAW A:id tHe MLIERs: Miso (1930); ARvold, Folklore of Capitalisar (1937); Robisson. Law asi the Lowvers (1935).

67. Notably Justices Brandeis, Stone and Cardozo of the Supreme Court of the United States. Justice Stephens of the United States Court of Apreals for the District of Columbia. Judge Hand of the United States Circuit Court uf Appeals, Judge Pound of the Jew York Court of Appeals, and Chief Justice Rosenberry of the Suprems Court of Wisconsin.

68. The development of a sound system of administrative justice "is nut iurthered by the mere substitution of the opinion of the judges for the opinion of administrative experts as to issues and matters peculiar to individual cases. Such substitution does not 
the second point which was selected for discussion - the judicial tendency to ignore the unique character of the functions vested in administrative agencies and its effect upon the exercise of discretion.

It must be obvious that the technical distinctions developed by the courts to justify their departures from the basic principle of administrative finality completely disregard the necessity for allowing administration to perform its discretionary functions within the area of legislative policy free from the restraining hand of the judiciary. Since the exercise of discretionary authority. involves all types of administrative determinations, the utilization of the fundamental or basic fact classification impinges upon the free exercise of discretion to the extent that the distinction is adhered to by the reviewing court. Furthermore, since the law-fact classification is at best a nebulous one, the judicial tendency is to exercise an independent judgment as to any determination which is not clearly and completely based upon a pure finding of fact. ${ }^{0 \theta}$ The reality of this tendency, as well as its unfortunate effects, are borne out by the history of the Supreme Court decisions relating to the review of the administrative determinations under the Federal Trade Commission Act. ${ }^{70}$ Neither space nor time permit a comprehensive examination of the various instances in which the courts have paralyzed the administration of legislative policy by interfering with the legitimate exercise of discretionary administrative authority. However, as long as the courts are guided in their control over administrative activities by distinctions of their own making which permit no freedom for the exercise of discretion, it must be assumed that the administrative agency is not fully. accomplishing the purposes for which it was established. And this observation is pertinent even with respect to those matters which the courts have described as "questions of law." Although the judicial distinction used to subject administrative determinations involving a statutory construction to an independent judicial supervision "has a plausible ring of rationality," 71 there can be no doubt that such control, when exercised, frequently results in a perversion of the legislative standard. In many instances the courts have held that the meaning of a statute, including the basic policy which was established to guide the administrative agency, is a question which must be finally determined by the judiciary rather than the agency established for that purpose. ${ }^{72}$ Thus the courts have not

subordinate discretion to law; it simply sets the discretion of an unqualified agency in the place of a qualified one. It piles one discretionary authority on top of another." Dickinson, supra note 2, at 297, 298.

69. See supra note 43.

70. See Landis, supra note 47 , at 534 .

71. Pound, Administrative Application of Legal Standards, (1919) 44 A. B. A. REPORT 445, 462.

72. The author is not unmindful of the fact that the courts must be permitted to exercise some degree of control over administrative action to avoid arbitrary and 
infrequently succeeded in converting an expression of legislative policy or standard of administrative action into a hard and fast issue of substantive law - which is precisely what the legislature sought to avoid by establishing an administrative agency to exercise a continuing supervision in its field of regulatory control. By this process of judicial usurpation the courts rather than the administrators have become the final arbiters as to the content and meaning of national legislative standards. ${ }^{73}$ As a practical matter the judiciary is no more fitted to enter the specialized fields of public administration, nor endowed with the technical competence necessary to solve the intricate problems arising in connection with the enforcement of modern legislative policies, than are the legislative bodies which were forced to delegate such functions to specialized tribunals. ${ }^{74}$ Obviously, then, the courts are in no position to supervise the exercise of discretionary authority by these specialized tribunals except in those cases where there is a clear abuse of power or authority. In any event it is difficult to justify the courts' position in attempting to substitute their own judgment in matters of discretion or legislative policy for that of an experienced administrative agency. Similarly, but to an even greater extent, the practice of permitting a complete trial de novo on certain fundamental issues which inevitably involve the exercise of dis-

capricious rulings. The question really resolves itself into one of how far the judicial function should extend. Questions of law, including the construction of statutes, have traditionally been determined by the judiciary. But it does not follow that the courts are the only agencies capable of interpreting the content of legislative standards. From a purely functional view-point, administration is more suitably equipped to ascertain the true legislative purpose in the establishment of complex policies than are the courts. Therefore, as in the case of administrative fact determinations, the province of the judiciary should be limited to the issue of reasonableness. The courts should not be permitted to search for the correct interpretation of a statute, after an administrative agency has attempted to make such a determination, but should merely inquire as to the reasoncbleness of the particular determination which has been made. This would allow the administrative authority to perform the functions for which it was established-3 function which incidentally is wholly legislative. See Landis, Business Policy ond the Courts (1937) 27 Y ALE REv. 235.

73. Due to the technical aspects of modern legislation it has become practically impossible to segregate pure questions of statutory interpretation from issues of legislative policy. In a large measure this is due to the imperfections of language which render precise judgments uncertain. Ske Professor Laski's Note in the REFont of rae Commritee on Ministers' Powers (His Mfajesty's Stationery Office, 1932). The essential reason why the judiciary is unsuited to pass upon questions of policy is beause they tend to give to the concept of private rights a pre-eminence which is incompatible with modern theories of government. In other words the judicial tendency is to construe statutes in such a manner as to protect private rights with little or no consideration of the social or economic policy which lies at the foundation of the law. Jennings, The Report On Ministers' Powers (1932) 10 J. Pun. Adsrs. 333.

74. See supra p. 580. 
cretion reaches beyond the outermost bounds of sound governmental practice.

On several occasions the courts have frankly recognized their own incapacity to deal with the difficult problem of governmental administration. In one such instance when Congress attempted to vest the judiciary with a jurisdiction to supervise certain administrative processes, the Supreme Court refused to permit the Federal courts to assume this task on the ground that they cannot constitutionally "exercise or participate in the exercise of functions which are essentially legislative or administrative." 75 It was indicated that if the courts were compelled to consider such administrative questions they would be acting beyond their judicial functions in violation of the doctrine of separation of powers. Yet these same courts claim the right to substitute their own independent judgment, on the basis of an entirely new judicial proceeding, with respect to the validity of administrative determinations which in their very nature are either "legislative or administrative" but certainly not judicial. In other and more frequent instances the courts have conceded the difficulty of their task and expressed the desire to rely upon the findings of administrative agencies in reaching their "independent" conclusions as to the validity of administrative determinations. Thus the Supreme Court has said that "there is a strong presumption in favor of the conclusions reached by an experienced administrative body" 70 and that they "will not be disturbed save as in particular instances they are plainly shown to be overborne." 77 The burden on a judge reviewing the legality of administrative action is admittedly a heavy one. But the mental gymnastics involved in simultaneously recognizing the "strong presumption in favor of the conclusions reached by an experienced administrative agency" and "exercising an independent judgment" as to the validity of such administrative determinations would appear to be beyond the capacity of even the greatest human intellect. And it is precisely for this reason that it is more important to emphasize what the courts actually do in reviewing administrative action rather than the abstract principles to which they have given mere lip-service in various judicial opinions on the subject.

Before concluding this section on judicial review it seems appropriate to indicate a few special problems arising from the peculiar character of discretion as related to its control by an external force. It has previ-

75. Federal Radio Commission v. General Electric Co., 281 U. S. 464, 469 (1930). See also Keller v. Potomac Electric Power Co., 261 U. S. 428 (1923) ; Postum Cereal Co. v. California Fig Nut Co., 272 U. S. 693 (1927).

76. Danwell v. Edwards, 244 U. S. 564, 5069 (1917).

77. St. Joseph Stock Yards Co. v. United States, 298 U. S. 38, 54 (1936). See also Heath v. Wallace, 138 U. S. 573, 582 (1891); Bates \& Guild Co. v. Payne, 194 U. S. 106, 109 (1904). 
ously been suggested that the primary purpose of investing the instruments of administration with a discretionary authority was to place the enforcement of legislative policies in the hands of officials who presumably possess a technical competence and specialized knowledge in their particular fields of governmental activity. In this respect the exercise of discretion is synonymous with the operation of a scientific government. Consequently, the efficiency of administration in performing its functions is reduced to the extent that its operations are controlled by external force which does not possess this indispensable degree of specialized ability. Whether the discretionary function is subject to a supervisory control by the judiciary or by any other non-expert body, the ultimate reşult is a perversion of the entire process. of administration. One of the more obvious effects of this external control is the inevitable tendency to crystallize the exercise of discretion by the formulation of general standards or rigid concepts which serve to confine the delegated authority within certain preconceived channels. While it may well be true that the gradual evolution of administrative action from discretion to predictable rule is a desirable situation, ${ }^{78}$ this development should come from within administration itself as the result of actual experience rather than by an arbitrary compulsion from an outside force. Not the least of the more desirable aspects of the delegation of discretionary authority is its inherent capacity to accommodate itself to the many unforseen problems that arise in the enforcement of general legislative policies. The establishment of external controls to supervise the exercise of discretion tends to reduce this element of flexibility in direct proportion to the extent that such compulsion is made effective.

Another effect of the external control of functional discretion concerns its tendency to "climb" from the rank and file of expert administrators to higher administrative officials in the face of such arbitrary supervision. Under ordinary circumstances the actual exercise of discretionary authotity, at least in the first instance, is placed in the hands of the non-political expert who possesses the requisite technical competence and knowledge to administer the more intricate aspects of modern legislation. The advice and recommendations of these expert administrators are generally accepted as a matter of course by their superiors, the higher administrative officials. When, however, the exercise of discretion by these experts is being subjected to an external supervisory control, there is a definite hesitancy or reluctance on their part to exercise the discretionary elements of the authority which has been intrusted to them. This places the burden of administering the details of legislative standards and policies on the shoulders of the higher administrative officials, who are not selected for their technical competence as much as for their

78. Pound, supra note 71, at 464 . 
executive or administrative ability. In addition to the unfortunate tendency to divorce the administrative specialist from the exercise of technical functions this condition also violates one of the cardinal principles of scientific management, the rule that authority should be coextensive with responsibility. Whether this is due to inertia, fear, or lack of confidence on the part of administrative experts is somewhat beside the point. The fact is that for some reason the exercise of discretion when subjected to an arbitrary control by a non-specialized body tends to rise to the higher levels of administration where it does not receive the vitalizing impetus of the administrative specialist which is so necessary to the complete effectuation of legislative policy. Without attempting to labor the point further it is sufficient to note that there is abundant evidence that the presence of external restraints on the exercise of discretion frequently causes a serious dislocation of the basic functions of administration and results in a perversion of its legitimate place in the process of government.

\section{ConcLuston}

One of the most serious impediments to the orderly development of a sound system of administrative justice is the assumption that the judiciary is the only agency of government which possesses the capacity to govern. There can be no doubt that the instruments of administration have been established in response to the growing demands of modern government which require, above all other things, the competence and knowledge of expert administrators. It is also abundantly clear that the courts are ill-equipped and poorly adapted to control the specialized activities of administration in the articulation of social and economic policies. In the past such judicial supervision has not only resulted in a substantial perversion of the legislative will but has also served to undermine the integrity of the administrative process. If modern government is to assume its proper responsibility in solving the fundamental and perplexing problems of the day with intelligence and foresight, administration must first be accorded a status of autonomy within the functional structure of the State. Not until an autonomous system of administration is recognized, free from the restraining hand of judicial absolutism, can we hope to obtain an assurance of administrative justice in the first instance. Existing theories of judicial review completely ignore this problem, since they are primarily concerned with the correction of "administrative errors" after they have occurred. Furthermore, it should be recognized that judicial supervision over administrative action does not usually concern itself with the quality or propriety of administrative activity. For the most part, the judiciary merely 
emphasizes what it conceives to be the fundamental safeguards for the protection of private rights. Pre-occupation with these theories of judicial superiority tends to shift the emphasis from sound administration, where it properly belongs, to median administration which merely seeks to follow the basic principles of natural justice.

The charge is frequently made that administration does not yet possess the competence, skill or ability to be trusted with these vast powers of discretionary authority without an active supervision from some outside source. In other words, there are many who believe that governmental administrators are just "political hacks" rather than administrative experts. The short answer to this charge is that for the most part it is not true. But if we assume that it were true, it would be well to inquire whether the existence of mediocrity might not have been caused, at least in part, by the existing tendency to subordinate administration to a place of inferiority within the framework of government. Thus the vicious circle becomes apparent. If the agencies of administration are constantly subjected to a stringent supervision by tribunals which are assumed to be superior in status and capacity, it becomes increasingly difficult to attract men of ability and competence to such positions of questionable responsibility. But the advocates of judicial supervision rationalize their demand for this control by charging that the presence of mediocre administrators prevents a relaxation of this traditional policy of supervision. The solution of this dilemma would appear to be in the selection of possible alternatives to the present confusing state of affairs. To those who are seriously interested in the integrity of administration and the improvement of administrative justice, the only acceptable solution will be in the direction of making authority coextensive with responsibility by permitting the development of a reasonable system of administrative autonomy. To those who distrust the exercise of administrative powers the only satisfactory solution will be in the direction of placing a greater and greater burden on the judiciary with either of two results. Either our judicial system will break down under the tremendous pressure of these new duties with which it is totally unfamiliar or the responsibilities of government will be decreased through the lack of instruments to carry its national policies into complete effectuation.

These observations are not without great political significance. Democracy is not a self-operating device for good government. On the contrary, the quality of democracy depends primarily upon the caliber of men who can be attracted to positions of responsibility and authority within its political framework. If the concept of an autonomous system of administration is generally considered to be irreconcilable with the indispensable safeguards against unlawful administrative action by reference to the assumption of judicial superiority, popular government vill 
inevitably give way to a more efficient form of political authority. Due to the increasing demand upon government to assume many new responsibilities of the most difficult character, the future of democratic government may depend, in a large measure, upon its ability to assimilate a responsible administrative system into the existing institutional structure without sacrificing fundamental political ideals. 